\title{
DOSSIÊ DOSSIER DOSSIER
}




\section{Apresentação do Dossiê Estudos sobre o Cristianismo Primitivo}

Os estudos de Novo Testamento estão passando por um processo de renovação nos últimos anos. Deixando de lado as abordagens tradicionais autoreferentes eles se lançaram em aventuras interdisciplinares que abriram perspectivas inusitadas. Principalmente com a chegada dos estudos culturais e discursivos a exegese do Novo Testamento conseguiu sair do solipsismo de disciplina teológica fundamental. Isso teve várias consequências para essa área de estudos. Dentre elas podemos citar que não se estuda mais exclusivamente o Novo Testamento. Os textos apócrifos e a literatura não-cristã passaram a ser incorporados às análises. Tampouco foi possível estudar o cristianismo isoladamente de seu contexto sócio-cultural. E internamente, o cristianismo também ganhou novas feições: não se estuda apenas o apostólico, tampouco exclusivamente hierarquias e autoridades masculinas. Entraram na discussão cristãos e cristãs comuns, de diferentes idades, profissões, estratos sociais, etc. Os temas não são apenas referentes às doutrinas, mas se referem também às práticas quotidianas, ao mundo doméstico, do trabalho às práticas religiosas.

Neste dossiê queremos oferecer uma contribuição específica, mas que tem o poder de mudar a perspectiva de estudo do conjunto histórico-cultural que chamamos de cristianismo primitivo: a sua relação com a cultura popular do Mediterrâneo. Nesse novo olhar, o cristianismo nascente não é analisado apenas como parte dos estratos sociais inferiores, partilhando de suas lutas e sofrimentos. Trata-se de apontar para o fato que os primeiros cristãos constroem suas referências simbólicas, narrativas e rituais a partir de categorias provenientes da cultura popular. Trata-se de uma inversão de perspectiva que nos dá novos olhares sobre o todo. O que antes ficava de fora da consideração da comunidade acadêmica, passa a ser central. Pensemos no caso 
específico das práticas mágicas: numa perspectiva neotestamentária e de história de instituições e doutrinas, seria um tema à margem, na perspectiva apontada, no entanto, central. Aprendemos com a religião do povo, no passado e na nossa sociedade, que religião sempre se conecta com as demandas domésticas, quotidianas, com o corpo. E o faz à sua maneira, articulando, memórias, textos, vozes, orações, aromas, incensos, etc. Trata-se de religião que tem densidade semântica, imagética, narrativa e performance. Ou seja, os símbolos religiosos se relacionam com os movimentos do corpo.

$\mathrm{Na}$ seleção de textos que compõem esse dossiê encontramos análises sobre diversos aspectos da cultura popular. Popular jamais é sinônimo de simples, de pouco sofisticado. Ao contrário: a religião praticada na periferia se caracteriza por inventividade e adaptabilidade. Ela tanto cria novos sistemas simbólicos, quanto recria o estabelecido em perspectivas ainda impensadas.

Os primeiros três artigos estão unidos por um tema comum: práticas mágicas no cristianismo primitivo. O primeiro texto, de Paulo Nogueira, promove a discussão sobre as práticas religiosas populares do cristianismo primitivo a partir de um material inusitado, a saber: os amuletos mágicos. $\mathrm{O}$ artigo insiste na necessidade de que as práticas mágicas e os rituais de poder dos primeiros cristãos sejam estudados a partir de uma perspectiva multiangular, que considere tanto a narrativa quanto a materialidade dessas práticas. O segundo, de Denilson Matos, estuda o fenômeno por outra perspectiva, igualmente importante, o das autoridades romanas do segundo século que perseguiam os cristãos por serem praticantes de magia. Isso nos ajuda a perceber os estigmas que eram criados contra as práticas mágicas das comunidades cristãs. Por fim, temos um tratado de demonologia judaico dos primeiros séculos da era cristã, o Testamento de Salomão, estudado por Elizangela Soares. Nele Salomão entrevista os demônios e os subjuga por meio de seu anel. Nessas entrevistas são reveladas as áreas de atuação dos demônios, os seus respectivos poderes astrais e os anjos que os subjugam. Magia neste bloco de artigos é, portanto, estudada desde a perspectiva interna, nas práticas e na imaginação religiosa, e na perspectiva externa, nos preconceitos e e esteriótipos da sociedade e do poder romano.

Num segundo grupo de textos nos encontramos com relatos do cristianismo primitivo que mostram sua relação com as formas populares da narrativa. Uma delas, abordada no artigo de Carlos Eduardo Mattos, estuda os relatos de viagem ais infernos, em especial o Apo- 
calipse de Pedro, no qual o apóstolo em viagem ao mundo do além contempla os sofrimentos e torturas dos pecadores. O segundo artigo, de Guilherme Cavalheri, analisa a presença de uma tradição folclórica que tem raizes profundas na cultura popular e no cristianismo primitivo: os animais falantes. Esses animais nos lembram que a nossa percepção dos animais, a partir de uma separação estrita entre animais e humanos e entre natureza e cultura não perpassa todos os níveis de nossa percepção.

O artigo de Danielle Frederico estuda a refeição e a comensalidade no cristianismo primitivo como espaço de adaptação e articulação de códigos culturais centrais da cultura popular. O cristianismo tem que se reinventar à mesa e no partir do pão.

Por fim, temos dois artigos que tratam de aspectos das práticas religiosas do povo em períodos diferentes do que é tratado pelos artigos elencados até aqui. Sua ligação com o dossiê é temática e metodológica e suas abordagens mostram que a abordagem enriquece a abordagem dos estudos de religião, em outras cronologias. O primeiro artigo, de Silas Klein, problematiza o conceito e discute magia na história da religião de Israel a partir de estudos de mídia e de cultura material em um selo de osso de Tell en-Nasreh. Por fim, Martin Barcala e Paulo Nogueira, estudam a relação entre medicina e magia, e entre feitiçaria e milagre divino, na obra da abadessa e mística medieval alemã, Hildegard von Bingen. Na sua obra Physica é possível observar as ambiguidades dos jogos retóricos das práticas religiosas populares em sua caracterização interna.

Por fim, gostaria de mencionar que estes artigos foram produzidos no âmbito do Grupo Oracula, da Pós-Graduação em Ciências da Religião da UMESP, durante a execução do projeto de pesquisa $O$ Cristianismo Primitivo como Religiosidade Popular do Mediterrâneo, que contou com financiamento da FAPESP e bolsa produtividade CNPq 2 para seu coordenador.

Prof. Dr. Paulo Augusto de Souza Nogueira Coordenador do Grupo Oracula de Pesquisa Organizador do Dossiê 